\title{
PENDIDIKAN AKHLAK: KOMPARASI KONSEP PENDIDIKAN IBNU MISKAWAIH DAN AL-GHAZALI
}

\author{
Nur Hamim \\ (Fakultas Tarbiyah IAIN Sunan Ampel Surabaya \\ Email: ulul_masedi@yahoo.com)
}

Abstract: History of Islamic ethical philosophy notes the debates and discrepancies among Muslim scholars. One of these is between Ibnu Miskawaih and al-Ghazali. While the former is known as the defender of rational thought, the latter is said to be the prime supporter of mystical tradition in Islam and is often accused of being the cause of defunct of critical Islamic thought. However, to what extent and in which context those differences occur have not been discussed sufficiently. To understand these differences clearly and to distinguish the core issues of the controversies between these two great Muslim scholars, this article aims to examine Miskawaih's and al-Ghazali's thoughts and analyze them in a dialogical framework. This comparative study investigates the ethical concept promoted by these two figures and focuses on other related issues, such as the basic notion of ethics, buman existential structure, the eminence of morality and elements of educational ethics.

Abstrak: Dalam sejarah perkembangan filsafat etika muslim, ditemukan adanya persimpangan jalan antara Ibnu Miskawaih dan al-Ghazali, di mana tradisi yang diwariskan oleh tokoh pertama biasa disebut sebagai tradisi rasional, sedangkan yang dititiskan oleh tokoh kedua disebut sebagai tradisi mistik. Untuk memperoleh kejelasan dan kejernihan format pola berpikir Ibnu Miskawaih yang oleh beberapa pibak disebut sebagai pendorong kemajuan, dan sebaliknya al-Ghazali yang dituduh oleh sebagaian pihak sebagai salah satu penyebab kemandegan laju dinamika gerak intelektual dalam dunia muslim, maka penulis mencoba mendialogkan pemikiran etik dua tokoh tersebut. Kajian ini dilakukan dengan analisis komparasi pemikiran konsep etika keduanya pada aspek; konsep dasar etika, struktur eksistensial manusia, pokok keutamaan akblak dan komponen pendidikan akblak.

Keywords: pendidikan akblak, akblak rasional, akblak mistik, Ibnu Miskawaih, al-Ghazali. 
KEHANCURAN ideologi komunis pada akhir abad XX bermula dari peremis anti Tuhan yang kemudian berubah menjadi anti manusia dengan segala kejahatan dan kezaliman yang dilakukan terhadap umat. Nampaknya pada abad yang akan datang, ideologi tersebut akan dikenang sebagai sisa-sisa peradaban yang tetap dikutuk orang. ${ }^{1}$ Sementara itu, kapitalisme yang masih berada pada masa kejayaan, menurut beberapa pengamat juga tidak dapat dijadikan alternatif bagi bangunan peradaban masa depan. Hal tersebut dikarenakan tabiatnya yang rakus, tidak bermoral, dan hanya dapat melahirkan masyarakat hedonistik di bawah selubung negara kesejahteraan (the welfare state). ${ }^{2}$ Menurut Herbert Marcuse, buah dari sistem kapitalisme ini ialah memudarnya dimensi bagian dalam dari pemikiran, pupusnya kekuatan kritis dari rasio, ketertundaan kepada fakta-fakta kehidupan. ${ }^{3}$

Bila kondisi kontemporer sekarang berada dalam kondisi ketidakamanan ontologis (ontological insecurity), ${ }^{4}$ maka merupakan kewajiban setiap orang untuk mencari dasar-dasar moral dan akhlak demi kelangsungan ras manusia di permukaan bumi.

Islam sebagai gerakan pembaharuan moral dan masyarakat, sejak awal abad VII secara tegas Nabi Muhammad saw. telah menyatakan bahwa tugas utamanya adalah sebagai penyempurna akhlak manusia. Al-Qur'an membenarkan dengan tegas bahwa ia adalah seorang yang berakhlak agung. ${ }^{5}$ Karena itu, ia patut dijadikan teladan bagi kehidupan. ${ }^{6}$

Dalam catatan sosio-historis, Islam pernah mengalami masa kejayaan dan kemunduran. Masa keemasan Islam terjadi antara 650-1250 M. Para sejarawan menyebut masa ini dengan periode klasik dalam sejarah perkembangan sejarah Islam. Umat Islam pada masa ini menjadi superpower yang menguasai sebagian besar negara-negara di tiga benua: Asia, Afrika, dan Eropa.

${ }^{1}$ Ahmad Syafi'i Ma'arif, “Agama dan Pembangunan: Corak Masyarakat Islam Masa Depan”, Ulumul Qur'an, Vol. III, No. I (1992).

2Joseph A. Cammileri, Civilization in Crisis: Human Prospect in a Changing World, (London: Cambridge University Press, 1979), 33.

${ }^{3}$ Herbert Mercuse, One Dimentional Man, (London: Abacus, 1972), 11.

${ }^{4}$ Cammileri, Civilization..., 36.

${ }^{5}$ Qs. al-Qalam (68): 4.

${ }^{6}$ Qs. a-Aḥzāb (33): 21. 
Wilayah kekuasaannya mencapai Spanyol di wilayah belahan Barat dan India di wilayah belahan Timur. Ketinggian dan kemajuan peradaban pada periode ini diabadikan sejarah dengan mencatat nama-nama seperti Imam Malik, Abu Hanifah, Syafi'i, Ibnu Hambal, al-Asy'ari, al-Maturidi, Wasil bin Atha', Zunnun al-Mishri, Abu Yazid al-Busthami, al-Kindi, al-Farabi, Ibnu Miskawayh, al-Ghazali, dan sederetan nama-nama lain dengan kebesaran karyanya masing-masing. Akan tetapi, sesudah masa tersebut umat Islam dilanda perpecahan dan kejumudan yang akhirnya membawa kemunduran. Selain berpindahnya daerahdaerah yang semula menjadi kekuasaan Muslim ke tangan Barat, masa ini juga tidak ditemukan lagi tokoh-tokoh ilmu pengetahuan seperti pada masa sebelumnya. Meskipun pada awal abad XIX Masehi Islam mulai bangkit kembali, tetapi sampai saat ini secara langsung ataupun tidak langsung Islam masih didominasi Barat. ${ }^{7}$

Penyebab kemunduran umat Islam menurut Harun Nasution adalah kurang memanfaatkan daya pikir yang dimilikinya, padahal ajaran Islam sangat mendorong penggunaan daya pikir tersebut. ${ }^{8}$ Karena itu, jalan untuk mendaki tujuan tersebut tidak lainkecuali dengan mengkaji ulang Islam secara bertanggungjawab dan terus menerus untuk memperoleh konsep-konsep kunci bagi penyelesaian masalah-masalah mendasar yang dihadapi.

Seperti yang telah disebutkan di atas, umat Islam periode klasik patut dijadikan acuan untuk memberikan arahan pendidikan masa sekarang, sebab sejarah telah membuktikan bahwa pendidikan pada periode klasik telah mampu memberikan motivasi terwujudnya masa keemasan Islam. Dalam pada itu, warisan khazanah kepustakaan Islam, banyak terdapat karyakarya tentang berbagai disiplin ilmu, diantaranya karya tentang pendidikan akhlak. Pengungkapan kembali pemikiran filsuf di bidang akhlak dimaksudkan sebagai bahan pertimbangan untuk mengambil konsep-konsep pendidikan akhlak yang layak untuk

${ }^{7}$ Harun Nasution, Pembaharuan dalam Islam: Sejarab Pemikiran dan Gerakan (Jakarta: Bulan Bintang, 1990), 12-4.

${ }^{8}$ Harun Nasution, Akal dan Wabyu dalam Islam (Jakarta: UI Press, 1983), $5-8$. 
dihidupkan kembali dan bisa diterapkan untuk pendidikan akhlak masa kini dan masa yang akan datang.

Pendidikan akhlak secara umum dibedakan menjadi dua kategori, yaitu pendidikan akhlak rasional dan pendidikan akhlak mistik. ${ }^{9}$ Perbedaan kedua jenis pendidikan akhlak tersebut berimplikasi pada tumbuhnya kreativitas dan inisiatif bagi akhlak rasional dan sebaliknya akhlak mistik kurang memotivasi manusia untuk aktif, kreatif, dan dinamis. Hal tersebut disebabkan adanya perbedaan pendekatan. Pendidikan akhlak rasional dari pendekatan ajaran Islam yang bukan semata sebagai doktrin yang absolut (pendekatan kemanusiaan). Sementara itu, pendidikan akhlak mistik melakukan pendekatan terhadap ajaran Islam sebagai ajaran yang absolut (pendekatan ketuhanan). Pendekatan kemanusiaan memiliki indikasi manusia bersifat otonom, sedangkan pendekatan ketuhanan menempatkan manusia pada makhluk yang heteronom. ${ }^{10}$

Salah seorang filsuf klasik yang dianggap bermazhab pendidikan akhlak rasional ialah Ibnu Miskawaih yang dibuktikan dengan salah satu karyanya, yaitu Taḅrib al-Akhlāq wa Tathir al-A'raf yang dijadikan rujukan oleh Muhammad Abduh dalam mengajarkan akhlak di rumahnya. ${ }^{11}$ Dengan demikian, menurut penilaian Rasyid Ridha, buku tersebut mendasari perilaku Muhammad Abduh yang dikenal sebagai tokoh pembaharu kontemporer dalam Islam. Diasumsikan pula dengan dijadikannya karya Ibnu Miskawaih sebagai buku pegangan dalam pengajaran akhlak oleh Muhammad Abduh, maka pemikiran akhlak Ibnu Miskawaih mampu memberikan motivasi bagi pemikiran pembaharuan dalam Islam.

Tokoh lain di samping Ibnu Miskawaih ialah al-Ghazali, yaitu seorang sufi sekaligus filsuf yang juga banyak berbicara tentang pendidikan akhlak. Hal tersebut bisa dilihat dari semua karya al-Ghazali khususnya Ihya' 'Ulüm al-Dìn, Fätịhat al-'Ulùm,

${ }^{9}$ M. Amin Abdullah, The Idea of Universality of Ethical in Ghazali and Kant(Ankara Turkey: Turkey Diyanet Vakfi, 1992), 193.

${ }^{10}$ Harun Nasution, Muhammad Abduh dan Teologi Rasional Mu'tazilah, (Jakarta: UI Press, 1987), 1-5.

${ }^{11 M u h a m m a d}$ Rashīd Riḍā, Tarikeh al-Ustādh al-Imām al-Shaykh Muḥammad 'Abduh, Juz I (Mesir: Matba'ah al-Manār, 1931), 135. 
Mizān al-'Amal, Mi'rāj al-Sälikìn dan Ayyuhā al-Walad. Adapun pemikiran al-Ghazali sejalan dengan filsafatnya yang religius dan sufistik. ${ }^{12}$

Atas dasar pemikiran tersebut, maka pemikiran pendidikan akhlak Ibnu Miskawaih dan al-Ghazali layak untuk dikomparasikan.

\section{Struktur Eksistensi Manusia}

Ibnu Miskawaih memandang manusia terdiri dari dua substansi: pertama, substansi yang berupa tubuh sebagai wawasan materi, dan kedua, jiwa (al-nafs), yaitu substansi yang tidak berdimensi sebagai wawasan imateri dan inilah yang menjadi esensi manusia. ${ }^{13}$ Al-Ghazali dalam buku filsafatnya ma'ärij alquds berpandangan sama dengan Ibnu Miskawaih, ${ }^{14}$ akan tetapi dalam buku tasawuf mi'räj al-sālikin menggambarkan manusia terdiri dari al-nafs, al-rūh dan al-jism. ${ }^{15}$ Dalam bahasan akhlak alGhazali mengistilahkan wawasan imateri dengan tiga istilah alrüh, al-nafs dan al-jism. Namun demikian, esensi manusia tetap sama yaitu al-nafs (jiwa).

Setelah itu baik Ibnu Miskawaih maupun al-Ghazali membagi jiwa (al-nafs) menjadi tiga bagian, Ibnu Miskawaih membahasakan tiga bagian tersebut dengan fakultas berfikir (alquwwah al-natiqah), fakultas amarah (al-quwwah al-gadabiyyah), dan fakultas nafsu syahwat (al-quwwah al-shahwiyab). ${ }^{16}$ Sedangkan alGhazali mengistilahkan fakultas berfikir dengan al-nafs alinsāniyyah (jiwa sebagai esensi manusia), fakultas amarah dengan istilah al-nafs al-hayawaniyyat, dan fakultas nafsu syahwat dengan menggunakan istilah al-nafs al-hayawaniyyah. ${ }^{17}$ Jelas sekali perbedaan yang terjadi pada aspek ini hanya ada pada

12Fatiyah Hasan Sulaiman, Konsep Pendidikan Akblak al-Ghazali, ter. Ahmad Hakim dan M. Imam Aziz (Jakarta: P3M, 1990), 4.

${ }^{13} \mathrm{Ibnu}$ Miskawaih, Meniju Kesempurnaan Akblak, ter. Helmi Hidayat (Bandung: Mizan 1994), 35.

${ }^{14} \mathrm{Al}-\mathrm{Gazāl} \overline{1}$, Ma'ārij al-Quds fi Madarij Ma'rifat al-Nafs (Kairo: Maktabah al-Jundidat, 1968), 19-24.

${ }^{15} \mathrm{Al}-\mathrm{Gazāi}$, Mi'raj al-Sälikìn (Kairo: al-Saqafah al-Islāmiyyah, 1964), 16.

${ }^{16}$ Ibnu Miskawaih, Menuju..., 43-4.

${ }^{17}$ Al-Gazālī, Mi'yār al-'Tlm, ed. Sulayman Dunya (Kairo: Dār al-Ma’ārif, 1960), 291. 
penggunaan istilah saja, namun pengertiannya tetap sama. Keduanya juga beranggapan bahwa jiwa al-natiqah (fakultas rasional) menduduki posisi yang tertinggi. Karena fakultas tersebut menjadi ciri khas seorang manusia.

\section{Pokok Keutamaan Akhlak}

Kesempurnaan manusia sangat terkait dengan keutamaankeutamaan (al-fadài $i)$ atau berfungsinya potensi yang dimiliki manusia sesuai dengan tuntutan kesempurnaan yang dimiliki manusia. ${ }^{18}$ Sebaliknya tidak berfungsinya potensi jiwa sesuai dengan tuntutan kesempurnaan itu dinamakan keburukankeburukan (al-radhä'il). ${ }^{19}$ Dengan demikian, keutamaan menuntut adanya keserasian tertentu dalam hubungan fungsional potensi yang dimiliki manusia. Ibnu Miskawaih dan al-Ghazali berpandangan sama dalam menjadikan doktrin jalan tengah (alwasāt) sebagai dasar keutamaan akhlak. Doktrin tersebut sebenarnya sudah dikenal para filsuf sebelumnya. Seperti Mencius (551-479 SM), yaitu filsuf Cina yang telah menulis buku tentang "The Doctrine of The Mean"atau doktrin jalan tengah. ${ }^{20}$ Juga para filsuf Yunani seperti Plato (427-347 SM), Aristoteles (384-322 SM), dan filsuf muslim seperti al-Kindi dan Ibnu Sina. ${ }^{21}$

Ibnu Miskawaih secara umum memberi pengertian jalan tengah (al-wasāt) tersebut dengan adanya sikap seimbang, moderat, harmoni, utama, mulia atau posisi tengah antara dua ekstrem kelebihan (al-tafrit) dan kekurangan (al-ifrät).

${ }^{18}$ Murad Wahab, dkk, al-Mu'jam al-Falsafi (Kairo: al-Saqafat al-Jadidat, 1971), 161.

19Ibid., 103.

${ }^{20}$ James Legge (pent.), The Four Book: Confucian Analects: The Great Learning, The Doctrin of The Mean, and The Work of Mencius (New Jersey: Princton University Press, 1963), 5.

${ }^{21}$ Plato, lihat, Plato, The Statements, Phlebus and Ion, ter. Harold N. Fowler dan W. R. M. Lamb (London: Harvard University Press, 1962), 253-73; Aristoteles, "Nicomachean Ethics" dalam The Work of Aristotle, ter., W. D. Ross (Chicago: The University of Chicago, 1952), 351-4. Dan, Al-Kindi lihat, Abd. Halm Mạ̣mud, Al-Afkir al-Falsafi fi al-Islam, (Bayrut: Dar alKitab al-Ulbani, 1982), 320-5. 
Dalam hal tersebut, Ibnu Miskawaih dan al-Ghazali sama dalam mengemukakan empat keutamaan tertinggi (ummahāh alfadhäì), yaitu al-hikemat sebagai keutamaan akal, al-shajä'ah sebagai keutamaan daya, al-gadab, al-iffah sebagai keutamaan daya alshahwah dan al-'adālah sebagai keseimbangan daya tersebut. ${ }^{22}$ Perbedaan antara Ibnu Miskawaih dan al-Ghazali dalam hal ini terdapat pada pandangan Ibnu Miskawaih yang sepakat dengan Aristoteles bahwa al-'adälah merupakan pertengahan antara teraniaya (al-inģiläm) dan aniaya (al-zulüm) yang memiliki banyak cabang, di antaranya persahabatan, kemampuan bekerjasama, kearifan dalam memutuskan persoalan, cinta, dan beribadah. Sedangkan al-Ghazali sependapat dengan Ibnu Sina yang memandang keadilan hanya memiliki satu lawan makna, yaitu aniaya (al-jawr) oleh karenanya tidak memiliki cabang. ${ }^{23}$

Ibnu Miskawaih dan al-Ghazali berpendapat bahwa alat yang dijadikan ukuran untuk memperoleh sikap pertengahan adalah akal, dan syariat. Akan tetapi Ibnu Miskawaih dalam menguraikan sikap tengah dalam berakhlak tidak mengutip alQur'an dan Hadis, sedangkan al-Ghazali melandasinya dengan landasan Islami yang diperkokoh dengan dalil-dalil al-Qur'an dan Hadis, seperti sikap sederhana dalam membelanjakan harta, makan, dan minum. ${ }^{24}$

Dari kemungkinan untuk mencapai posisi pertengahan al'adälah. Al-Ghazali berpendapat bahwa hanya Rasul yang dapat mencapai posisi pertengahan itu, sedangkan manusia biasa hanya mampu mendekati dan tidak mampu untuk mencapainya. ${ }^{25}$ Akan tetapi Ibnu Miskawaih, sebagaimana Aristoteles dan alFarabi secara optimis berpendapat bahwa siapa pun dengan memperhatikan aturan-aturan tertentu, akan sangat mungkin untuk memperoleh posisi pertengahan al-'adälab tersebut. ${ }^{26}$

${ }^{22}$ Al-Gazālī, al-Ma'ärij al-Quds..., 92; Ibnu Miskawayh, Taḥdhìb alAkbläq..., 46-9.

${ }^{23}$ Lihat, Muhammad Ahmad Syarif, Ghazali's Theory of Virtue, (Albany: State University of New York Press, 1975), 178-80.

${ }^{24}$ Mahmud, Al-Tafkir...,325.

${ }^{25}$ Nasution, Filsafat..., 26.

${ }^{26} \mathrm{Ibn}$ Miskawayh, Tạ̣dhib al-Akbläq wa Tathir al-'Araq, ed. Hasan Tamim (Bayrūt: Manshūrat Dār al-Maktabah al-Hayat, 1938), 46; 
Pendapat tersebut tentunya bila diterapkan dalam dunia pendidikan, akan berimplikasi bagi motivasi usaha. Konsep Ibnu Miskawaih lebih memberi peluang bagi kesungguhan usaha yang terus-menerus disertai sikap optimis untuk dapat memperolehnya, sedangkan al-Ghazali sebaliknya membuat seseorang pesimis untuk mencapai moral ideal.

Dari keempat pokok keutamaan akhlak tersebut yang membedakan antara al-Ghazali dan Ibnu Miskawaih adalah pada kebijaksanaan (al-bikmah), keberanian (al-shajāab), menjaga kesucian diri (al-iffah), dan keadilan (al-'adälab).

Kebijaksanaan (al-hikmah)

Baik al-Ghazali maupun Ibnu Miskawaih berpendapat bahwa al-hikmah adalah pertengahan antara dua ekstrem kelebihan (al-iffah) dan kekurangan (al-tabrit), hanya yang membedakan keduanya adalah dalam memberikan istilah. Ibnu Miskawaih menggunakan istilah al-safah (kelancangan) untuk ekstrem kelebihan, sedangkan al-Ghazali menggunakan istilah alkhibb (penipu yang lihai). Untuk kedua istilah tersebut al-khibb mengandung arti yang lebih dalam dari pada al-safah. Meskipun keduanya menggunakan istilah al-balah untuk ekstrem kekurangan, namun keduanya memberi pengertian yang berbeda untuk istilah al-balah tersebut. Al-Balah menurut Ibnu Miskawaih diartikan "kekurangan kemauan", sedangkan al-Ghazali mengartikan "kurangnya kualitas jïwa 'aqilat". ${ }^{27}$

Empat keutamaan akhlak tersebut memiliki cabang. Untuk al-hikmah, Ibnu Miskawaih menyebut tujuh cabang keutamaan, yaitu: 1) ketajaman intelegensi (al-zaka $\vec{a}), 2)$ kuat ingatan (alDhiker), 3) rasionalitas (ta'aqqü), 4) tangkas (sur'at), 5) jernih ingatan (shafa al-zibn), 6) jernih pemikiran (jawdat al-zibn) dan 7) mudah belajar (subūl al-ta'lum). ${ }^{28}$ Sedangkan al-Ghazali hanya menyebut lima macam keutamaan al-hikmah, yaitu: 1) pemikiran yang baik (busn al-tadbir), 2) pemikiran yang jernih (jawdat al-zibn), 3) pendapat yang cemerlang (saqabat al-ra'y), 4) prediksi yang

\footnotetext{
Muhammad Abdul Quasem, The Ethic of Ghazali: a Composite Ethic in Islam, (Selangor Malaysia: Central Printing Sendirian Berhard, 1975), 101.

${ }^{27}$ Musa, Al-Falsafat..., 160-1.

${ }^{28}$ Ibn Miskawayh, Taḥdhib..., 4.
} 
tepat (ithbāt al-zann) dan 5) selalu menyadari kesalahan dan kekotoran jiwa meskipun yang paling halus sekalipun (al-tafathun li daqä'iq al-'amal wa khafāyāāfät al-nufüs). ${ }^{29}$

Dilihat dari urgensi perolehan al-hikmah atau kebijaksanaan dalam pendidikan akhlak adalah seseorang akan bersikap dan bertindak arif lagi bijak dalam menyikapi segala persoalanpersoalan hidup yang amat kompleks, baik atas nama individu yang berhubungan langsung dengan al-khäliq maupun dalam hubungannya dengan lingkungannya. Sehingga ia akan menemui kebahagiaan dalam sikapnya tersebut.

Keberanian (al-shajä'ah)

Keberanian adalah keutamaan dari daya amarah (al-gadab) karena mendapat bimbingan dari al-hikmah, keutamaan dari jiwa al-natiqah. Dan sifat ini adalah pertengahan antara pengecut (aljubn) dan nekad (al-tahawwur). Selain al-Ghazali dan Ibnu Miskawaih, Aristoteles, al-Farabi, serta Ibnu Sina juga berpendapat demikian. ${ }^{30}$

Sifat al-shaja'ah, al-jubn, dan al-tahawwur sangat terkait dengan sifat marah. Dalam memberi batasan sifat marah yang tidak tercela antara Ibnu Miskawaih dan al-Ghazali berselisih pendapat. Ibnu Miskawaih mengatakan batasannya adalah akal dan syara', sedangkan al-Ghazali lebih menekankan pada batasan syara'. ${ }^{31}$ Hal ini terlihat juga pada pendapatnya tentang pertimbangan dalam mengambil keputusan keberanian untuk memperoleh kematian yang mulia, al-Ghazali menitikberatkan pertimbangannya hanya pada akibat setelah kematian, sedangkan Ibnu Miskawaih pada sisa kehidupan seandainya tidak mengambil alternatif tersebut di samping pada akibatnya setelah kematian.

Sebagaimana al-hikmah, al-shajā'ah juga memiliki cabang. Ibnu Miskawaih menyebutkan sembilan cabang untuk al-shajäab, yaitu jiwa besar (kibār al-nafs), keberanian (al-najdäd), ketenangan ('iz̧am al-bimmat), keuletan (al-sabat), kesabaran (al-șabr),

${ }^{29} \mathrm{Al}-\mathrm{Gazā} \overline{1}$, Mizàn..., 274.

${ }^{30}$ Syarif, Ghazali's..., 44.

${ }^{31} \mathrm{Ibn}$ Miskawayh, Taḥdhīb..., 106; Al-Gazālī,al-'Arba'ìn fì Ușul al-Dìn, (Bayrūt: Dār al-Jil, 1988), 136. 
kemurahan hati (al-hilm), menahan diri ('adam al-taysy), keperkasaan (al-shahamat), dan senang bekerja (ibtimal al-kadd). ${ }^{32}$ Sedangkan al-Ghazali menyebutkan sepuluh cabang, yaitu kemuliaan (al-karam), keberanian (al-najdadd), keperkasaan (alshahamat), jiwa besar (kibār al-nafs), ketahanan (al-ibtimal), kemurahan hati (al-hilm), tahu diri (al-waqar), dan kerahaman (altawaddu)..$^{33}$

Perbedaan antara Ibnu Miskawaih dan al-Ghazali terlihat dalam memasukkan cabang-cabang keutamaan. Kalau al-Ghazali memasukkan kemuliaan (al-karam) sebagai cabang dari al-shajäah, sedangkan Ibnu Miskawaih memasukkan al-karam sebagai cabang menjaga kesucian diri (al-iffah). Ibnu Miskawaih memasukkan kesabaran (al-sabr) ke dalam dua keutamaan alshajäah yang diartikan sabar dalam menghadapi masalah-masalah berat dalam al-iffah, sabar di sini diartikan menahan nafsu dari segala kelezatan yang berakibat buruk. Sedangkan al-Ghazali memasukkan sabar sebagai cabang dari al-shajäab dengan pengertian yang kedua. Al-waqar dikategorikan al-Ghazali ke dalam cabang al-shajäah dan Ibnu Miskawaih memasukkan dalam cabang al-iffah. Perbedaan ini karena al-Ghazali meletakkan al-waqar sebagai sikap pertengahan antara takabbur dengan tawaddu' dengan arti menempatkan diri pada tempat yang semestinya karena mengetahui kadar kemampuan dirinya. ${ }^{34}$ Sedangkan Ibnu Miskawaih mengartikan al-waqar sebagai ketenangan dan keteguhan jiwa ketika menghadapi sesuatu. ${ }^{35} \mathrm{Al}$ Ghazali juga memasukkan al-karamdan al-nubl ke dalam cabang al-shajā'ah, sedangkan Ibnu Miskawaih memasukkan ke dalam sub cabang al-iffah. 36

Perbedaan antara Ibnu Miskawaih dengan al-Ghazali dalam mengkategorikan cabang-cabang kemuliaan tersebut dikarenakan kedekatan maknadan pengertian dari cabang-cabang tersebut, juga karena keterkaitan antara keutamaan daya-daya tersebut dalam sistem dan fungsinya.

${ }^{32}$ Ibn Miskawayh, Tạ̣dhīb...,42.

${ }^{33}$ Al-Gazālī, Ibyya', Juz III, 53.

${ }^{34}$ Al-Gazālī, Mizàn..., 276.

${ }^{35}$ Ibn Miskawayh, Tạdhib..., 42.

${ }^{36}$ Ibid. 


\section{Menjaga kesucian diri (al-iffah)}

Ibnu Miskawaih dan al-Ghazali sepakat meletakkan al-iffah sebagai pertengahan antara rakus (al-sharah) dan dingin hati (kbumūd al-shahwat), keduanya juga sepakat jika akal dan syara' dijadikan barometer dalam menentukan posisi tengah tersebut. ${ }^{37}$

Al-iffah sebagai keutamaan daya jiwa al-shabwiyah sangat erat terkait dengan kebutuhan fisik manusia, seperti makan, minum, berpakaian, dan seksual. Untuk mengatur kesemuanya ini bagi anak-anak adalah dengan pembiasaan dan latihan. Kaitannya dengan pendidikan akhlak, keutamaan ini akan terwujud manakala orang tua juga guru selalu mengarahkan dan membimbing sampai akhirnya mereka terbiasa dengan keutamaan-keutamaan yang dimaksud.

Al-iffah memiliki cabang lebih banyak dari pada dua keutamaan sebelumnya, baik yang dikemukakan Ibnu Miskawaih maupun al-Ghazali. Akan tetapi bila diamati lebih jauh bisa diambil kesimpulan, bahwa keduanya mengutamakan keselamatan jiwa pribadi meskipun dalam porsi yang berbeda. Perbedaan ini terlihat ketika Ibnu Miskawaih memasukkan enam cabang pada kedermawanan (al-sakha) sebagai sifat sosial, maka al-Ghazali hanya memberikan tiga cabang untuk al-iffah yang berkenaan dengan keutamaan sosial. ${ }^{38}$ Dari perbedaan tersebut bisa diambil kesimpulan bahwa terlihat akhlak al-Ghazali bersifat sufistik individual, sedangkan akhlak Ibnu Maskawaih lebih bersifat akhlak sosial.

Keadilan (al-'Adālah)

Al-'adālah akan terwujud pada diri seseorang manakala adanya integritas dan keserasian antara tiga keutamaan jiwa albikmah, al-shaja'ah dan al-iffah. Oleh karenanya al-Ghazali berpendapat bahwa al-'adälah tidak memiliki cabang, hanya yang ada satu lawan dari keadilan adalah ketidakadilan (al-jawr). Berbeda dengan al-Ghazali, Ibnu Miskawaih berpendapat bahwa keadilan adalah pertengahan antara aniaya (al-zulum) dan teraniaya (inziläm) juga memiliki cabang-cabang, yaitu bersahabat

${ }^{37}$ Ibid., 47.

${ }^{38}$ Lihat, Syarif, Ghazali's..., 65, 184-5. 
(al-shadaqat), baik dalam bekerjasama (busn al-sharikab), kearifan dalam memutuskan persoalan (busn al-qada), cinta (tawadud) dan beribadah (al-íibädab).

Untuk era sekarang agar doktrin jalan tengah tidak kehilangan barometer dan tetap relevan, maka doktrin jalan tengah bisa dipahami sebagai doktrin yang mengandung nuansa dinamika. Artinya adanya tarik-menarik antara kebutuhan, peluang, kemampuan, dan efektivitas. Sehingga ukuran "akhlak pertengahan" pun akan selalu berubah sejalan dengan laju perkembangan zaman, yang termasuk ikut menentukan di dalamnya adalah laju pertumbuhan dan perkembangan ekonomi, sosial, politik, dan budaya. Contoh konkretnya, ukuran kesederhanaan bagi masyarakat bawah berbeda dengan kesederhanaan bagi masyarakat kelas menengah, dan atas, demikian seterusnya ukuran-ukuran kebaikan bagi empat keutamaan yang lain (al-hikmah, al-shajā'ah, al-iffah, dan al-'adālah).

Dari perbedaan-perbedaan tersebut nampak jelas kalau Ibnu Miskawaih membangun teori etikanya merujuk kepada pernyataan-pernyataan moral al-Qur'an dan al-Sunnah dengan ketelitian abstraksi dan analisis dengan menggunakan metodemetode dan kategori-kategori filsafat. Oleh karenanya, menurut Madjid Fakhry, konsep etika Ibnu Maskawaih adalah etika moralitas skriptual. ${ }^{39}$ Sedangkan konsep etika al-Ghazali adalah etika religius, ${ }^{40}$ karena teori etikanya berakar dari konsepsi alQur'an, al-Sunnah, konsep-konsep teologi, kategori-kategori filsafat, dan sufisme. Sebenarnya etika inilah yang memiliki karakteristik paling Islami, namun sayang al-Ghazali belum bisa memadukannya secara harmonis, sehingga kecemerlangan pendapatnya terkurung dalam baju sufi.

\section{Komponen-komponen Pendidikan Akhlak}

\section{Tujuan}

Pendidikan pada dasarnya menurut al-Ghazali adalah pendidikan akhlak, sehingga ia merumuskan tujuan

${ }^{39}$ Madjid Fakhry, Etikea dalam Islam, ter., Zakiyuddin Baidhawy, (Yogyakarta: Pustaka Pelajar, 1996), xxi-iii.

${ }^{40}$ Ibid. 
pendidikanuntuk menghilangkan akhlak yang buruk dan menanamkan akhlak yang baik. ${ }^{41}$ Selanjutnya dalam kitab "Maw'idzāt al-Mu'minin" ia menerangkan hakikat akhlak adalah keadaan atau konstitusi jiwa yang tetap (konstan) yang menjadi sumber lahirnya perbuatan secara wajar, mudah tanpa memerlukan pertimbangan dan pikiran. Dan pada akhirnya, secara lugas al-Ghazali mengemukakan dua tujuan yang akan dicapai; pertama, kesempurnaan manusia yang bertujuan mendekatkan diri kepada Allah. Kedua, kesempurnaan manusia yang bertujuan untuk mencapai kebahagiaan dunia dan akhirat. Sedangkan Ibnu Miskawaih merumuskan tujuan pendidikan akhlak, dalam tahdhīb al-akhlāq, ialah terwujudnya pribadi susila, berwatak luhur, atau budi pekerti mulia. Dari budi (jiwa/watak) lahirlah secara spontan pekerti yang mulia sehingga mencapai kesempurnaan dan memperoleh sa'adat (kebahagiaan yang sempurna). Selanjutnya Ibnu Miskawaih menjelaskan bahwa manusia tidak dapat mencapai kesempurnaan dengan hidup menyendiri, tetapi harus ditunjang oleh masyarakat.

Perbedaan yang mendasari rumusan tujuan pendidikan akhlak Ibnu Miskawaih dan al-Ghazali tersebut adalah pada metodologi perolehan kesempurnaan. Ibnu Miskawaih menggunakan metode analitis, sedangkan al-Ghazali menggunakan metode hipotesis. Perbedaan tersebut adalah: pertama, kesempurnaan yang dimaksud Ibnu Miskawaih tidak akan diperoleh dengan sendirinya, tetapi harus dengan masyarakat. Hal ini menandakan bahwa sifat akhlak Ibnu Miskawaih adalah akhlak sosial. Sedangkan menurut al-Ghazali kesempurnaan bisa dilakukan dengan praktek asketik, sehingga sifat akhlak al-Ghazali adalah monolitik. Kedua, kesempurnaan dalam pandangan Ibnu Miskawaih dan al-Ghazali adalah kesempurnaan praktis dan teoretis. Yang pertama (kesempurnaan praktis) berfungsi menggerakkan tubuh melalui daya-daya jiwa sensitif, sesuai dengan tuntutan pengetahuan yang dicapai oleh akal teoretis, dan kesempurnaannya ialah kesempurnaan karakter, yaitu dengan menertibkan fakultasfakultas jiwa sehingga tidak saling berbenturan, namun hidup di dalam dirinya secara harmonis. Kesempurnaan yang pertama ini

$$
{ }^{41} \text { Madjid, Konsep..., } 86 .
$$


erat kaitannya dengan kesempurnaan yang kedua (kesempurnaan teoretis) yang bersifat imateri, dan abstrak serta berhubungan dengan pengetahuan-pengetahuan yang abstrak, dan universal. Sedangkan kesempurnaannya adalah dengan memperoleh pengetahuan yang paling tinggi yang bersifat abstrak, dan universal. Ibnu Miskawaih berpendapat pengetahuan ini diperoleh dengan akal perolehan (al-'aql al-mustafad). Akal perolehan ini akan mampu menerima pancaran al-bikmat dari akal aktif (al-'aql al-af'al), adapun caranya adalah dengan usaha yang sungguh-sungguh dalam mempertajam daya pikir. ${ }^{42}$ Sedangkan menurut al-Ghazali pengetahuan yang tertinggi adalah diperoleh dengan intuisi (al-dhawq) dengan cara mempertajam daya al-dhawq melalui pembersihan diri dari dorongan-dorongan duniawi untuk dapat bersatu dengan Tuhan. Persatuan dengan Tuhan akan menyingkap segala rahasia dan hakikat-hakikat. 43

\section{Materi}

Ibnu Miskawaih tidak membeda-bedakan antara ilmu-ilmu agama dan yang non agama. Adapun yang menyangkut materi untuk pendidikan akhlaknya, ia menyebutkan tiga meteri pokok, yaitu: (1) hal-hal yang wajib bagi kebutuhan tubuh, (2) hal-hal yang wajib bagi kebutuhan jiwa, dan (3) hal-hal yang wajib bagi hubungan sesama manusia. ${ }^{44}$ Ketiga pokok materi tersebut dapat diperoleh dari dua sumber, yaitu: (1) ilmu-ilmu rasional (al-úūm al-fikriyyat), dan (2) ilmu-ilmu empiris (al-ulùm al-hissiyah).

Berbeda dengan Ibnu Miskawaih, al-Ghazali mengklaster ilmu pengetahuan menjadi dua bagian besar, yaitu ilmu agama dan non agama. Dari dua bagian besar tersebut dikelompokkan menjadi tiga kelompok, yaitu: (1) ilmu-ilmu yang terpuji, (2) ilmu-ilmu yang tercela, (3) ilmu-ilmu yang terkadang terpuji, dan sebaliknya. Dan juga al-Ghazali menyebutkan tiga sumber ilmu pengetahuan, yaitu: (1) ilmu-ilmu rasional yang diperoleh dengan penggunaan rasio, (2) ilmu-ilmu empiris yang diperoleh dengan

${ }^{42}$ Ibn Miskawyh,"Fi al-'Aql wa al-Ma'qul”, dalam Arabica, (Leiden: Swets \& Zeitlinger BV., Vol. XI, 1964), 85; Qs. al-Qalam (68): 4.

${ }^{43}$ Nasution, Manusia..., 36.

${ }^{44} \mathrm{Ibn}$ Miskawayh, Tạ̣dhib..., 116. 
penginderaan, dan (3) ilmu al-kasyäf yang diperoleh dengan intuisi (al-dhawq).

Dari klasifikasi pengetahuan yang diajukan al-Ghazali yang perlu mendapat sorotan diantaranya adalah ilmu-ilmu yang berfungsi mempertajam intelektual dan menjernihkan pemikiran, seperti Matematika dan Sains sebagai cabang dari filsafat, dianggap ilmu-ilmu yang sangat berbahaya karena ilmu-ilmu tersebut berakibat pada keracunan dan kekacauan pemikiran yang jika diterapkan pada kajian metafisik bisa menimbulkan kekafiran. ${ }^{45}$

Konseksuensi pandangan al-Ghazali tersebut adalah pada pembentukan pola pikir (system of thaught) kaum muslimin. Dan implikasinya adalah pada sikap umat Islam dalam menyikapi ilmu pengetahuan, yaitu secara perlahan tapi pasti mematikan dan melemahkan semangat keilmuan yang kritis dan historis. Sehingga menurut Fazlurrahman, al-Ghazali paling tidak, ikut bertanggungjawab terhadap kemunduran umat Islam dalam Sains, dan teknologi. ${ }^{46}$

Untuk menumbuhkan kembali pola pikir yang aktif, kreatif, progresif, dan inovatif, kiranya perlu dihidupkan kembali materimateri pengajaran akhlak Ibnu Miskawaih yang bernuansa filsafat dengan berbagai cabangnya dengan bangunan epistemologi yang Islami. Sehingga diharapkan dapat menghantarkan generasi yang akan datang menjadi tuan rumah pada era tinggal landas, dan bukan hanya menjadi tamu.

\section{Pendidik dan Peserta Didik}

Ibnu Miskawaih dan al-Ghazali sama-sama berpendapat bahwa pendidik pertama adalah orang tua. Hal ini bisa dimaklumi karena orang tualah penyebab kelahirannya. Dan kiranya keduanya juga mendasarinya dengan Hadis yang sangat populer yang diriwayatkan oleh Imam Muslim: "setiap anak, terlahir dalam keadaan suci. Kedua orang tuanyalah yang akan membentuknya menjadi Nasrani atau Yabudi".

${ }^{45}$ Montgomery Watt, The Faith and Practice of al-Ghazali, (London: George Allen \& Unwin, 1953), 33.

${ }^{46}$ Abdullah, Studi..., 251. 
Selanjutnya keduanya sangat menghargai dan memandang tinggi derajat seorang pendidik, sehingga Ibnu Miskawaih menempatkan derajat pendidik di antara orang tua dan Tuhan, dan menjulukinya sebagai bapak ruhani (wälid rubani) dan orang yang paling mulia (rabb bashari). Derajat ini menurut Ibnu Miskawaih hanya bisa diperoleh oleh para filsuf dan para Nabi. ${ }^{47}$ Sedangkan menurut al-Ghazali diperoleh oleh para Nabi, wali, dan para sufi. ${ }^{48}$ Alasannya adalah karena pendidiklah yang dapat membawa peserta didik kepada kearifan, mengisinya dengan kebijaksanaan yang tinggi dan menunjukkan kepada kehidupan dan kebahagiaan abadi. Dengan mendudukkan para sufi sebagai wälid ruhani, tanpa memasukkan filsuf, maka semakin jelaslah corak etika sufistiknya al-Ghazali. ${ }^{49}$

Tugas seorang pendidikan adalah membekali, memelihara, dan mengembangkan seluruh aspek kepribadian menuju pertumbuhan yang sehat dan sempurna, baik yang berkenaan dengan fisik, ruhani, intelektual maupun akhlak. Untuk itu, fungsi pendidik dalam mengembangkan potensi-potensi manusia-jasmani, akal-pikiran, keimanan, akhlak, keindahan, dan sosial kemasyarakatan—secara maksimal, serasi, dan harmonis, sehingga diharapkan sistem pendidikan yang demikian akan mampu melahirkan sumber daya manusia (SDM) yang berkualitas, plus berakhlak mulia.

\section{Lingkungan}

Berdasarkan premis bahwa setiap karakter dapat diubah, ${ }^{50}$ maka Ibnu Miskawaih dan al-Ghazali sangat memperhatikan faktor pengaruh lingkungan dalam pendidikan akhlak. Dari hasil telaah kedua tokoh tersebut dapat disimpulkan bahwa ada tiga lingkungan utama yang sangat mempengaruhi pendidikan akhlak, yaitu: (1) lingkungan keluarga dengan orang tua sebagai figur sentral; (2) lingkungan sekolah dengan guru sebagai figur sentral, dan (3) lingkungan masyarakat dengan figur sentralnya adalah tokoh-tokoh masyarakat.

\footnotetext{
${ }^{47}$ Ibn Miskawayh, Tạ̣dhib..., 133.

${ }^{48}$ Fatiyah, Konsep..., 33.

${ }^{49}$ Ibid., 12.

${ }^{50}$ Ibnu Miskawaih, Menuju..., 58. Lihat al-Gazālī, Ibyya', Jilid III, 69.
} 
Dari ketiga lingkungan pendidikan tersebut al-Ghazali menambahkan bahwa unsur makanan dan minuman yang menjadi sumber energi bagi pembentukan kepribadian juga sangat menentukan. ${ }^{51}$ Karena begitu erat kaitan antara makanan yang dikonsumsi tubuh dengan pembentukan kepribadian, maka Islam sangat memperhatikan masalah makanan, sebagaimana tersebut dalam al-Qur'an, "makanlah di antara rezeki yang baikbaik yang kami berikan kepadamu". ${ }^{2}$

Hubungan tersebut jika dilihat dari ilmu kesehatan menunjukkan bahwa makanan yang dikonsumsi akan berfungsi: pertama, sebagai zat tenaga. Tubuh manusia memerlukan tenaga untuk bekerja dan bergerak. Tenaga ini diperoleh dari hasil pembakaran zat-zat makanan di dalam tubuh. Yang termasuk zat tenaga ini adalah protein, hidrat arang, dan lemak. Kedua, sebagai zat pembangun. Tubuh manusia sejak berbentuk pembuahan sampai menjadi tubuh yang sempurna mengalami proses pertumbuhan dengan terjadinya sel-sel baru untuk membentuk bagian-bagian tubuh. Yang termasuk zat pembangun ini adalah mineral, protein, dan air. Ketiga, sebagai zat pengatur. Gerak dan suhu tubuh perlu diatur agar tetap berlangsung dengan baik dan tetap normal. Oleh karena itu, tubuh memerlukan zat pengatur yang terdiri dari vitamin, mineral dan air. ${ }^{53}$

Sebagai kaitannya makanan dengan pembentukan kepribadian adalah gizi yang berupa material akan menyehatkan badan (materi) dan halal sifat tak berwujud (imateri) yang melekat pada makanan berimplikasi pada kesehatan mental (imateri).

\section{Metode}

Pemikiran-pemikiran terkait metode pendidikan akhlak Ibnu Miskawaih dan al-Ghazali memiliki kesamaan visi, yaitu sebagai strategi untuk mencapai tujuan yang telah ditetapkan oleh keduanya. Pada dasarnya semua metode yang diterapkan oleh Ibnu Miskawaih dan al-Ghazali bisa juga diterapkan pada

${ }^{51}$ Al-Gazālī, Ibya', jilid III, 70.

${ }^{52}$ Qs. al-Baqarah (2): 172.

53Pemda DKI, Materi Dakwah Terurai, Jakarta: Proyek Peningkatan LBIQ DKI Jakarta, 1990), 186. 
pengajaran akhlak sekarang ini, akan tetapi yang perlu dicermati para pendidik dalam menggunakan metode adalah jangan sampai terjebak pada metode yang bersifat instruksional, dan doktriner. Kenyataan yang terjadi di Indonesia, pengajaran akhlak khususnya di pesantren-pesantren dan sekolah-sekolah agama masih dilakukan dengan metode hafalan, sehingga kurang memberikan prioritas ke arah penerapan pemahaman yang dianggap lebih penting dalam proses berlangsungnya belajar mengajar. Untuk dapat mengarah ke sana perlu ditekankan pada pendidikan akhlak adalah metode yang dapat menghantarkan peserta didik untuk menemukan sendiri nilai yang akan dikembangkan dengan cara mengenal terlebih dahulu komponen-komponen akhlak yang terdiri dari: (1) Memilih segisegi kognitif; (a) dengan bebas dan terbimbing, (b) dari berbagai alternatif, dan (c) sesudah mengadakan pertimbangan mengenai akibat-akibat pilihan; (2) Menghargai segi-segi afektif; (a) merasa bahagia dan gembira atas pilihannya, dan (b) mau menegaskan pilihan di depan umum; (3) Menghargai segi-segi psikomotorik; (a) berbuat sesuatu untuk pilihannya, dan (b) diulang-ulang kembali sehingga terbentuk suatu pola. ${ }^{54}$

Kunci pembentukan akhlak dalam proses pendidikan menurut Ibnu Miskawaih dan al-Ghazali menunjukkan bahwa manusia itu lahir dengan fitrah yang baik. Kepercayaan akan adanya fitrah tersebut akan mempengaruhi implikasi-implikasi praktis bagi metode-metode yang seharusnya diterapkan dalam proses belajar mengajar.

Dalam proses pendidikan akhlak, metode yang tepat guna, bila ia mengandung nilai-nilai yang intrinsik dan ekstrinsik sejalan dengan materi pendidikan dan secara fungsional dapat dipakai untuk merealisasikan nilai-nilai ideal yang terkandung dalam tujuan pendidikan Islam. Antara metode, kurikulum dan tujuan pendidikan Islam mengandung relevansi ideal dan operasional dalam proses kependidikan. ${ }^{55} \mathrm{Wa}$ al-Lāh a lam bi alsawāb.

${ }^{54}$ M. Sastrapratedja, Pendidikan Nilai Memasuki Tabun 2000, ed., EM. K. Kaswardi, (Jakarta: Gramedia Widiasarana Indonesia, 1993), 4.

${ }^{55}$ M. Arifin, Ilmu Pendidikan Islam (Jakarta: Bumi Aksara, 1993), 198. 


\section{Daftar Pustaka}

Abdullah, M. Amin. 1992. The Idea of Universality of Ethical Norms in Gharali and Kant. Ankara: Turkiye Diyanet Vakfi. . 1996. Studi Agama: Normativitas atau Historisitas.

Yogyakarta: Pustaka Pelajar.

Arifin, M. 1989. Ilmu Pedidikan Islam. Jakarta: Bina Aksara.

Aritoteles. 1982. Nicomachean Ethics in the Work of Aristotle. ter. W.

N. Ross, Chicago: The University of Chicago, 1982.

Camilleri. 1976. A Civilization in Crisis: Human Prospects in a Changing World. London: Cambridge University Press.

Fakhry, Madjid. 1996. Etika dalam Islam, ter. Zakiyuddin Baidhawy. Yogyakarta: Pustaka Pelajar.

Al-Gazālī, Muḥammad ibn Muḥammad. 1964. Miẓān al-'Amal, ed. Sulayman Dunya, Mesir: Dār al-Ma‘ārif.

. 1961. al-Munkìdh min al-Dalāl. Kairo: Silsilāt al-

Tsaqofah al-Islamiyyah.

. tt. Ibya' 'Ulüm al-Din, Kairo: 'Isa al-Baby al-

Halaby, juz II, III.

Mesir: Dār al-Ma'ārif.

. 1968. Ma'àrij al-Quds fi Madarij Ma'rifat al-Nafs,

Kairo: Maktabat al-Jundidat.

Islāmiyyah.

. 1964. Mi'raj al-Sälikin, Kairo: al-Thaqafat al-

Dār al-Ma'ārif.

1960. Míyär al-Tlm, ed. Sulaiman Dunya. Kairo:

Ma'arif, Syafi'i. "Qur'an Agama dan Pembangunan Corak Masyarakat Islam Masa Depan”, Ulum Al-Qur'an, Vol. III, No. III, No. 1 Thn. 1992.

Marcuse, Herbert. 1992. One Dimensional Man. Landan: Abacus.

Madjidi, Busyairi. 1997. Konsep Kependidikan Para Filosof Muslim, Yogyakarta: Al-Amin Press.

Maḥmūd, 'Abd. Hilmī. 1982. al-Tafkir al-Falsafi fi al-Islam, Bayrūt: Dār al-Kitāb al-'Ulbani.

Miskawayh, Ibn. 1938. Tạ̣dhib al-Akbläq wa Tațir al-'Araq, ed. Hasan Tamim. Bayrūt: Manshūrat Dār al-Maktabah alHayat. 
. 1994. Menuju Kesempurnaan Akhlak. ter. Helmi Hidayat. Bandung: Mizan. . "Kitab al-'Aql wa al-Ma'qul", dalamArabica, Leiden: Swetz \& Zeitlinger B. V., vol. XI, 1964.

Mūsā, Muhammad Yūsuf. 1963. Falsafah al-Akhlāq fi al-Islām wa Silatuhu bi al-Falsafah al-Igriqiyyat. Kairo: Mu'assasah al-Kanji. Nasution, Harun. 1983. Akal dan Wabyu dalam Islam. Jakarta: UI Press. 1990. Pembaharuan dalam Islam: Sejarah Pemikiran Gerakan. Jakarta: Bulan Bintang. . 1987. Filsafat dan Mistitisme dalam Islam. Jakarta: Bulan Bintang. . 1987. Mubammad Abduh dan Teknologi Rasional Mu'tazilah, Jakarta: UI Press.

Nasir, Yasir Muhammad. 1996. Manusia Menurut al-Ghazali, Jakarta: Srigunting.

Pemda DKI. 1990. Materi Dakwah Terurai. Jakarta: Proyek Peningkatan LBIQ DKI Jakarta.

Plato. 1962. The Statetemen, Philebus and Ion, ter. Harold N. Foeler, W. R. M. Lamb, London: Harvard Universitiy Press.

Quasem, Muhammad Abul. 1975. The Ethics of al-Gharali: a Composite Ethics in Islam, Selangor Malaysia: Central Printing Sendirian Berhard.

Ridla, Muhammad Rasyid. 1931. Tarikh al-Imām al-Syaikh Mubammad Abduh, juz I. Mesir: Mathba' al-Manar.

Sheriff, Ahmad Muhammad. 1975. Ghazali's Theory of Virtue, Albany: State University of New York Press.

Sulaiman, Fatiyah Hasan. 1990. Konsep Pendidikan Akblak alGhazali, ter. Ahmad Hakim dan M. Imam Aziz. Jakarta: P3M.

Wahab, Murad, dkk. 1971. al-Mu'jam al-Falsafi, Kairo: al-Saqafat al-Jadidat.

Watt, W. Montgomery. 1953. The Faiht and Practice al-Ghazali, London: George Allen \& Unwin. 